《國立䓨灣大學哲學論評》第三十七期 (民國九十八年三月), 121-162

(C) 國立臺灣大學哲學系

\title{
對朱喜在《知言疑義》中 批評胡宏的方法論反省
}

\author{
杜保瑞*
}

\section{摘 要}

本文討論《知言疑義》中朱喜對胡宏的批評意見, 企圖澄清雨造 思路的差異, 從而各自呈現雨家思維的特色與要點。《知言疑義》中 胡宏的文向多半是本體工夫論合構的發言, 因此語多跳躍, 致引朱 喜之批評。朱喜即由性善論的本體論立場批評胡宏有「性無善惡」之 說, 及由存有論思路的「心統性情說」批評胡宏的心性相關語句之不 佳, 以及由「未發涵養已發察識」的工夫次第思路批評胡宏並未重視 平日涵養一節。本文將藉由作者所提之「實踐哲學的解釋架構」, 以 及「存有論哲學」的問題意識分析, 以澄清雨造哲學問題意識的不同, 因而並未形成真正的衝突, 從而亦藉此說明朱喜與胡宏各自論學之 重點意旨。

關鍵詞：胡宏、朱喜、存有論、性善論、工夫次第論

杜保瑞, 臺灣大學哲學系副教授。

投稿：98 年 2 月 20 日; 修訂：98 年 3 月 13 日; 接受刊登, 98 年 3 月 14 日 


\title{
The Methodological Reflection about the Criticism to Hu Hong in The Doubt of Zhi Yan by Zhu Hsi
}

\author{
Bau-Ruei Duh ${ }^{*}$
}

\begin{abstract}
The discussion in this article is about the criticism to Hu Hong in The doubt of Zhi yan Proposed by Zhu Hsi. The author is aiming to clear the dissimilar way of thinking between the two philosophers to the effect that both their significant theory could be appeared. Hu Hong's philosophical announcement always integrates the ontological and practical theory, which results to the ambiguity and give rise to the criticism from Zhu Hsi. Zhu Hsi possessed the position of the goodness of nature to query Hu Hong about his no good and no evil opinion toward the theory of the human nature. In the definition of the mind and nature, master Zhu Hsi proposed the mind comprise the nature and the felling and argued with $\mathrm{Hu}$ Hong's different opining. Concerning about the practical procedure theory, Zhu Hsi insist the cultivation should be built on daily life, and critic Hu Hong's philosophy being short of this understanding. In this article the author will use the interpretational structure of the practical theory and the theory of being to analyze the different consciousness in these two systems and suggest that there exist no real conflict between them so as to explain both their philosophical thinking.
\end{abstract}

Keywords: Hu Hong, Zhu Hsi, the theory of being, the goodness of nature, the practical procedure theory

Associate Professor, Department of Philosophy, National Taiwan University. 


\title{
對朱喜在《知言疑義》中 批評胡宏的方法論反省
}

\author{
杜保瑞
}

\section{一、前言}

胡宏之學, 因稟承家學之故 ${ }^{1}$, 多能論於歷史評價, 見於其《知言》 一書。然《知言》中亦多有論於天道性命之學者, 頗受當代學者重視, 所述之筆力亦雄渾剛毅, 似張載 ${ }^{2}$ 。後人於其所述易有理解之困難, 弟子 張南軒即不能全解師意而有疑問, 轉與朱喜討論, 朱喜則以他自己的用 語方式及論理模型以評論胡宏, 卻多有誤解。胡宏之學精練而言寡, 語 其所論未網羅義理之全備則可, 評其所論有義理之誤謬則不必。胡宏前 有二程後有朱喜, 他在哲學史上的地位本不彰顯 ${ }^{3}$, 然朱喜疑義《知言》,

1 其父胡安國即為治春秋之史家。胡安國於《胡氏傳家錄》中言：「某初學春秋，用功十年， 遍覽諸家, 欲求博取以會要妙, 然但得其糟粕耳, 又十年, 時有省發, 遂集眾傳, 附以已說, 猶未敢以為得也。又五年, 去者或取, 取者或去, 已說之不可於心者, 尚多有之。又五年, 書成, 舊說之得存者宾矣。及此二年, 所習似益察, 所造似益深, 乃知聖人之旨益無窮, 信 非言論所能盡也。」《宋元學案》卷三十四, 武夷學案。〈文定胡武夷先生安國〉錄：「著春 秋傳進覽, 除賽文閣直學士。」

2 《宋元學案・五峰學案・序錄》中錄: 「其所作《知言》, 東萊以為過於《正蒙》, 卒開湖湘 之學統。」。筆者所謂似張載指得是胡宏之哲學思路, 亦屬窮探力索思辨深痕的型態, 因語 向中往往連結太多問題及主張的轉折, 以致文句難解, 然若對準問題意識, 亦得以準確理解 而有清晰的思路之呈現。但若給予總體評價, 筆者認為胡宏還是不如張載。

3 當代學者頗有以胡宏學為分判宋明儒學系統的關鍵人物, 因此胡宏學在當代的評價中有若千 
因有《知言疑義》之出, 胡宏之學因其與朱喜理路之差異而受到當代的 注意, 牟宗三先生即於 《心體與性體》書中盡詮《知言疑義》之全文, 其疏理亦實詳密。惟牟先生義理架構龐大綿遠, 非盡解牟學者亦難以藉 其所著而知朱胡兩家之意旨, 更何況, 牟先生有強勢的個人詮釋意見, 他高舉胡宏之餘卻將朱喜過於貶抑, 而這是筆者不認同的地方。本文之 作, 即欲就《知言疑義》中朱喜對胡宏之批評意見進行疏理, 企圖還原 胡宏述學之理路，亦藉此澄清朱喜論述之脈絡。

本文之討論將分三階段進行論述，第一階段針對朱喜與胡宏兩造哲學 理路之基本性格差異提出說明。第二階段說明《知言疑義》中的問題意識 宗旨。第三階段即針對《知言疑義》之文本逐段分析, 以使此一哲學衝突之 理路詳細明析, 而有以消解朱胡之辯, 此一消解非謂朱胡並無差異, 而是說 朱胡之差異及朱喜所提之衝突意見事實上是兩造所關心的哲學問題不同所 致, 筆者即企圖以哲學問題不同因此表面主張有異的方式解消兩造之衝 突，至於所謂的哲學問題即是以「實踐哲學」的「本體論、宇宙論、工夫 論、境界論 」的四方架構 ${ }^{4}$, 與「存有論哲學 」為基本哲學問題的分析架構 5

《知言》是《胡宏集》中討論哲學問題的專輯名稱，《知言疑義》實是 朱喜批評胡宏之作，書中有朱喜、張南軒、及呂東萊三人互相討論胡宏《知 言》書中之若干義理，放在《知言疑義》中的《知言》文句其實已沒有被 編輯在《知言》一書中了，這都要拜胡宏弟子張南軒之賜，張南軒實為胡

系統是給予極高地位的, 但筆者並不這麼認為, 並另有專文討論, 一方面批評當代的評價意 見, 二方面呈現胡宏學的理論面貌。参見: 杜保瑞, 〈對胡五峰哲學的當代詮釋之反省〉, 《台 北大學中文學報》, 5 期, 2008 年 9 月, 頁 71-107。杜保瑞, 〈論胡宏從誠仁心性道物說的 儒學建構〉, 《哲學與文化》, 34 期 8 卷。

4 實践哲學的解釋架構」是筆者與陳榮華教授合著《哲學概論》書中論及中國哲學的知識論課題 的一章, 参見: 杜保瑞, 陳榮華合著, 《哲學概論》, 臺北：五南出版社, 2008 年 1 月。文中提 出以「宇宙論、本體論、工夫論、境界論」為解釋架構, 來討論具有實踐哲學特質的中國哲學。

5 「存有論哲學」指得是一般西方哲學傳統中所討論的形上學問題, 就它的問題意識及思路的 特徵亦有在中國哲學中的相類似的型態, 便將這類的中國哲學討論稱為「存有論哲學」。本 文所討論的朱喜思想中就有許多存有論哲學的思路 
宏弟子 ${ }^{6}$, 《知言》書中張南軒並為之作序, 然而張南軒在與朱喜討論《知 言》時的意見卻偏向朱喜而批評胡宏，因此剔除了若干胡宏的文句，而僅 出現在《知言疑義》中。牟宗三先生對其甚為不滿, 認為他義理能力薄弱, 不足成家 ${ }^{7}$ 。此一態度亦為筆者之態度, 筆者也認為胡宏之說容有義理跳 躍、用詞險峻之狀, 但意旨仍是清晰可解, 且對儒學源流實有準確之傳承, 張南軒與朱喜對胡宏的言論實是誤解, 特別是做為胡宏弟子的張南軒, 其 義理論述最終只是成了一個小號的朱喜而已。本文為討論意旨集中起見, 將略去張南軒之意見。至於呂東萊, 他主要是歷史學家, 其為人、做官、 及論學之事業在朱喜的時代皆極有影響力, 在朱胡及朱陸之爭中皆有角色 扮演, 在理學研究的基本功力亦不差, 但哲學史上的地位則不如朱胡之重 要, 為討論集中起見, 呂東萊的意見亦略去不談。就本文對《知言疑義》 之討論而言, 即是朱喜與胡宏兩大系統為主。

\section{二、朱喜與胡宏哲學理論之基本性格疏解}

胡宏之學, 主要即是對先秦至北宋傳統儒學的繼承, 就儒學理論創造 的深度而言, 應只是一般以上的水平, 倒是朱喜在《知言疑義》中的認真 對辯的事件，突顯朱喜哲學創作的特色，因而胡宏之學亦以此而顯現其哲

6 《宋元學案・五峰學案》之附錄中記有: 「初, 南亁見先生, 先生辭以疾。他日, 見孫正儒 而告之。孫道胡宏之言日: 『渠家好佛, 宏見他說甚! 』南軒方悟不見之因。於是再謁之, 語甚相契，遂授業焉。南軒日：『栻若非正儒，幾乎迷路。』」《南軒學案》中錄：「少長，從 胡宏胡先生問程氏學。胡宏一見, 知其大器, 即以所聞孔門論仁親切之指告之。先生退而思, 若有得也。胡宏日: 『聖門有人, 吾道幸矣! 』」。

7 參見牟先生言: 「張南軒師事胡五峰, 然『受教之日淺』, 固不能發揮其師之精總。又其天資 明敏, 心思活潑, 看似通達柔和, 而實稟性清弱, 故其與朱子往復辨難, 率多以朱子為主動, 順從朱子之格局。其所言說大都尾隨其後而彌縫之, 或時加轉語, 稍見清妙, 未能精發師要, 挺立弘規, 故於朱子之格局, 毫不能有所點撥也。此觀其與朱子往復論中和以及《知言疑義》 即可知矣。此見其力弱才短, 故軟塌而被吞没也。其學無傳, 亦非偶然。朱子樂與之談, 而

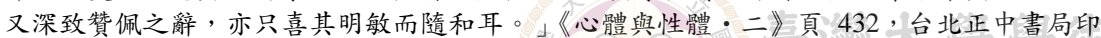
行, 1983 年 5 月台修五版。 
學史之意義。就胡宏而言, 牟宗三先生給了一個極高明的型態定位的評價, 認為是從《易傳》、《中庸》的形上系統到孔孟心性工夫系統的中間環節, 亦即胡宏既講天道性命, 又講盡心工夫, 實是上下兩路的結合, 而此一型 態即是儒學的正統, 亦即儒學義理發展的必然出路 ${ }^{8}$ 。筆者認為, 牟先生所 說只是一般宋明儒者皆有的基本程度, 胡宏只是繼承之而在發言之而已, 他既講本體論又講工夫論, 更會講要求做工夫的話, 甚而有印證境界的語 錄型發言 ${ }^{9}$, 但是因為胡宏在理論建構時的細節分析的力道不足, 因此在 若干章節中確實有高妙難解甚而語意跳躍之情形，朱喜即因不解而誤解。

至於朱喜的哲學性格則是問題意識明確, 且意見陳述都是立場鮮明 的。朱喜作為一位有創造力的哲學家, 便是因為他建構了不同於以往的 哲學理論, 重點不在他對儒學有新的價值立場，而是他論述的儒學有明 確的問題意識, 亦有明確的思考及討論的脈絡, 並且最終的意見多半清 晰明確而能成就系統者, 故而能成就他的一代大家。哲學史上以朱喜為 北宋五子之集大成者，實是朱喜採摘自己對五子所述中有深度反省及高 度興趣之理論部分而綜合創造者。五子一一各自成家，不在一特殊思辨 脈絡中則是無法籠統地集合為一的，故而朱喜之集大成實仍為一創造。

筆者認為, 朱喜的哲學理論建構在幾個重要領域中都是極有特色 的, 有形上學的也有工夫論的, 就形上學的思路而言, 朱喜主要是在進

8 參見牟先生言: 「此盖承北宋濂溪、横渠、明道之會通《中庸》、《易傳》而言道體, 即本天 命於穆不已之體而言性體, 而復本明道之『識仁』, 以會通孔子與孟子所言之本心, 而以心 著性也。此以由《中庸》、《易傳》言道體、性體為首出者, 所必應有之恰當之義也。……五 峰是承北宋之以《中庸》、《易傳》為首出者必然地要開出此義, 而即恰當地開出之, 此種開 出是有其自《中庸》、《易傳》回歸到《論》、《孟》之發展上之必然性與恰當性。」《心體與 性體・ 二》, 頁 431 。筆者對牟先生說胡宏本身思路的意見並不反對, 只是對胡宏的理論地 位以及整套宋明儒學系統的相關定位有意見，筆者另有它文討論，此處暫不多論。

9 所謂境界印證的語錄型發言, 即其發言内容是藉言說以提點學人之心境狀態, 是在言語中直 接做工夫而上下印心之事, 而不是在討論中言說知識, 因此用語多跳躍, 文義的認識甚且易 有正相對反之情事, 莊子及禪宗中多有此類話語。胡宏亦偶有之, 而朱喜即多不解, 《知言 疑義》中所批評的就包括這一類的發言。 
行一個存有論的概念分析工作, 是去說明認識世界的思考架構中的重要 範疇的概念定義及其相互關係, 這就是抽象思辨的認識進路的存有論哲 學 ${ }^{10}$, 這種抽象思辨的認識活動是以形上道體、天地萬物、價值實踐主 體的人性存有者、無形的鬼神存在等為對象, 對指涉這些對象的概念進 行定義及關係解析的活動, 如「天、地、理、氣、道、物、心、性、鬼、 神」等, 從而定位人們對整個生活世界的認識架構, 這也當然是哲學活 動的核心功能, 筆者即以「存有論哲學」的名義界定此學, 而與「本體 論哲學」以談價值意識為主者之使用有所區分, 價值意識的討論則是如 「仁、義、禮、智、誠、善、苦、空、無為、逍遙」等。

朱喜哲學的一大特色就是這種「存有論哲學」, 它並不純然是為道德 實踐活動而設，它是為包括道德實踐活動在內的一切人類活動而設定的 認識世界的思考模型。這種哲學活動牟宗三先生以之為本體論下的存有 系統 ${ }^{11}$, 也就是筆者所定義下的 「存有論哲學」, 是對於存在世界的種種 存有類項進行存在特性的意義界定。

在牟先生的術語使用中另有貫串價值意識與主體實踐而為 $「$ 本體工夫 論」之哲學問題, 但是牟宗三先生亦稱之為存有論的哲學問題, 只強調 此種存有論是為一「即存有即活動的存有論 」筆者以為 , 牟先生論說 $「$ 即 活動」時即已論說至 $「$ 工夫論」了, 因此與其說是 「存有論」, 不如說是 $\ulcorner$ 本體工夫論」, 其中包含 $「$ 價值意識的本體論」及 $「$ 主體實踐的工夫論」, 而這兩個哲學問題在一個實踐活動中必然是上下貫串的 ${ }^{12}$, 從而成為實踐

10 抽象思辨的認識進路是為討論概念定義的存有論之學, 由於中國哲學多涉及價值立場及工夫 修養之學, 哲學體系中並以此為大宗, 故而純粹討論抽象定義的存有論之學較不易為人察覺 其問題的獨立特性, 多被混入討論價值立場的本體論哲學中來認識, 朱喜之學即多有此類抽 象思辨義的存有論意味, 故多能與西方哲學會通、發皇、討論之。

$11\ulcorner$ 此是以大學為標準所開之漸教, 對《論》、《孟》、《中庸》、《易傳》言, 根本上為歧出。此 一系統主觀地說是認知的靜涵靜攝之系統, 客觀地說是本體論的存有之系統 (理是只存有而 不活動者）。」《心體與性體・ニ》頁 511 。

12 以上的討論, 參見筆者過去的論文：杜保瑞，2001年 7 月，〈當代宋明儒學研究與中國形上 
哲學的四方架構中的核心環節。就術語使用之考量言, 存有論這個哲學 術語如果限定在只作為討論存有類項的概念界定之學，則是語義清晰 的, 如果又要作為討論實踐活動的本體工夫之學, 而說為動態的存有論, 則是不易說清楚的。胡宏多為實踐哲學的本體工夫論思路, 而朱喜卻多為 $\ulcorner$ 抽象思辨的存有論哲學」, 特別是, 當朱喜批評胡宏語意有問題時即是 以此一立場在堅持的, 這當然跟朱喜在存有論之學說中有重要的創造有 關, 雖然如此, 我們仍不能說朱喜不討論或無所知悉於本體工夫之學 ${ }^{13}$ 。 事實上，朱喜對胡宏的批評還有一項重點即是以「性善論」的本體論為立 場, 批評胡宏一些本體工夫論的言說是為「性無善惡論」者, 這當然是朱 喜的誤讀，但這就證實了朱喜也一樣有價值義的本體論之重要發言。

以上是形上學中的存有論與本體論之概念及問題之重新定位, 這是 朱胡之爭的一個重點, 另就工夫理論而言, 朱喜論學的特色卻是在基本 人格的基礎訓練問題上，因此強調知識的豐富及平素的涵養，亦即入手 工夫以及工夫次第的問題。就工夫活動本身而言, 胡宏既是本體工夫的 路數, 就必然是注重主體的價值領悟及意志貫徹的思路, 用力在說明工 夫論在實踐主體及價值本體兩造間的扣合之意義。而朱喜則在工夫修養 問題上注意的是一般人都應該有的基本學識及能力的教育訓練的問題, 因此是人格養成教育的工夫次第問題, 而不只是本體工夫的問題。當然, 就本體工夫這個基本的儒家工夫修養論問題而言，朱喜亦非不解，更非 無知, 亦絕對不是不討論, 只是朱喜更關心下學上達的基本教育訓練問 題, 而且理論的辯爭亦總是不自覺地站在這個基礎上發言, 這顯然是現

學問題意識〉, 《輔大哲學論集第三十四期》頁 147-192。杜保瑞, 2001 年 4 月, 〈對牟宗三 宋明儒學詮釋體系的方法論反省〉, 《哲學雜誌第三十四期》頁 120-143。

13 金春峰教授即以心學進路演繹朱學, 實為對朱喜之學是有討論本體工夫亦深知本體工夫之實 況作申述, 以一改向來學界對朱喜認識之片面性, 此義筆者完全同意, 朱喜確有關於本體工 夫之學, 亦有如陽明、象山之直貫簡潔生動有力之作, 然而卻少受注意, 向來學界對朱喜的 形象認知是不識工夫只管概念的, 這也與朱喜自己的雄讋力爭有關, 朱喜自己是要負責的 参見：金春峰著, 《朱喜哲學思想》, 台北, 東大, 1998 年 5 月。 
實感受的經騟過於強烈所致，因此總是在這個層面上與論說本體工夫路 數的其它儒學理論進行辯爭, 關鍵在朱喜往往看到了講本體工夫的系統 之學者自己有流於任意的缺點。然而一旦朱喜也談本體工夫理論的時 候，朱喜的語言其實是與程影、胡宏、甚至象山之說都是一致的。金春 峰教授所著《朱喜哲學思想》一書, 幾乎就是為朱喜辯解此義而作的, 書 中多引朱喜發表本體工夫論的文句以為明證。就本體工夫而言, 牟宗三先 生說這一路是儒學的義理必然，是《論、孟》心學及《庸、易》形上學的 合構, 此說筆者完全同意, 既然是儒學義理之必然, 則朱喜亦是不能反對 的, 事實上朱喜根本沒有反對, 因為他自己也進行了同樣的本體工夫的 論述。問題只在他很注重這個基本訓練的工夫次第問題, 又恐怕是對某 些人的不信任從而以人廢言地否定了他的本體工夫的論述, 轉而從基本 教育訓練的工夫次第問題脈絡中與他人辯論, 牟宗三先生批評朱喜所強 調的工夫路數是為「別子為宗」, 亦即這個基本教育訓練的工夫次第進路 之思路也不是不對, 但它不是貫串形上道體的意志純化的本體工夫理 論，而本體工夫才是《論、孟、庸、易》一貫發展地在處理的問題。

\section{三、朱喜批評胡宏的論述主旨}

由於本文以《知言疑義》之材料及論述為解析對象，而《知言疑義》 實是以朱喜有所疑義之 《知言》文本而節選之材料, 是朱喜的問題意識 在決定該書的討論進程, 因此以下之討論即以朱喜之問題意識為脈絡來 為論述。

朱喜自述他對胡宏《知言》的批評意見如下：

$\ulcorner$ 《知言》中議論多病, 近疏所疑, 與敬夫、伯恭議論。如心以 成性, 相為體用, 性無善惡, 心無生死, 天理人欲同體異用, 先 
識仁體然後敬有所施, 先志于大然後從事于小, 此類極多。又其 辭意多急迫, 少寬裕, 良由務以智力探取, 全無涵養之功, 所以 至此。然其思索精到處, 何可及也。」14

朱喜此處之要目差不多即是《知言疑義》中之段落主題, 後文將詳 為陳述解析, 文中說胡宏用詞急迫而不寬裕, 說是務以智力探取的結果, 筆者以為, 這正是思辨力強的哲學作品的一般狀況, 張載的語句就有這 種現象, 但胡宏之作品, 也確實有跳躍過多致生疏漏的缺點。朱喜之批 評有以存有論思路批評胡宏的本體工夫語者, 即「心以成性, 相為體用, 心無生死」幾節; 有以性善論的本體論批評胡宏為「性無善惡」的本體 工夫語, 即「性無善惡, 天理人欲同體異用」幾節 ; 有以工夫次第批評 胡宏本體工夫語者, 如 $「$ 先識仁體然後敬有所施, 先志于大然後從事于 小」幾節。黃宗喜對於朱、胡《知言疑義》之重點要目則析分為八項：

$\ulcorner$ 宗羲案：朱子謂《知言》可疑者，大端有八：性無善惡，心為 已發, 仁以用言, 心以用盡, 不事涵養, 先務知識, 氣象迫狹, 語論過高。然會而言之, 三端而已：性無善惡, 一也。心為已發, 故不得不從用處求盡; 「仁, 人心也」; 已發言心, 故不得不從用 處言仁; 三者同條, 二也。察識此心, 而後操存, 三也。其下二 句, 則不過鿷氣之間。愚以為胡氏主張本然之善, 本自無對, 便 與惡對, 蓋不欲將氣質之性混入義理也。心為已發, 亦自伊川初 說有「凡言心, 皆指已發」而言, 以其未定者為定爾。察識此心 而後操存, 善觀之, 亦與明道識仁無異; 不善觀之, 則不知存養 之熟, 自識仁體。有朱子之疑, 則胡氏之說未始不相濟也。」15

14 《宋元學案・卷四十二・胡宏學案・附錄》

15 《宋元學案・卷四十二・胡宏學案》。本文附於《知言疑義》文末 
黃宗羲也說胡宏「氣象迫狹, 語論過高」, 但他說這是 $「$ 不過辭 氣之間」, 黃宗羲顯然要會通朱、胡, 認為兩造根本就有可能會通, 這也正是筆者本文寫作的傾向, 不過筆者並無意強為會通, 而是用力 在疏理其異, 使其差異呈顯而各自殊途, 一旦理解表面差異是因為問 題意識之不同而來的, 則兩造間的根本義理即有會通之可能。就黃宗 羲所述之重點項目而言, $\ulcorner$ 性無善惡, 一也」即是朱喜以性善論的本 體論批評胡宏用詞跳躍的本體工夫語; $「$ 心為已發, 二也。」即是朱 喜以「心統性情」的存有論批評胡宏的本體工夫語者; 「察識此心, 而後操存, 三也。」即是朱喜以工夫次第問題批評胡宏的本體工夫 語者。

不論是朱喜自述還是黃宗羲所述, 當然都是朱喜與胡宏差異之大 要, 但這仍是古人疏理的脈絡, 以筆者的研究工具來說, 則朱喜對胡 宏批評的主要路線為：第一、朱喜以心統性情之存有論批評胡宏 ; 第 二、朱喜以性善說的本體論批評胡宏 ; 第三、朱喜以涵養重於察識之 工夫次第論批評胡宏。以上三項之胡宏所言皆是本體工夫語, 另有第 四項、朱喜不解胡宏之境界印證的語錄體著作之意旨。以上是筆者經 由哲學基本問題解析之後的歸整, 這也是本文分析 《知言疑義》中的 文義之有效工具。

\section{四、對《知言疑義》的文義疏解}

以下, 筆者將以前述義理脈絡疏解 《知言疑義》, 此處之討論不只是 要指出朱喜之錯誤理解為目的, 而是要以指出朱喜哲學創造的路線為更 重要的目的。 


\section{（一）「盡心成性」的本體工夫與「心統性情」的存有論 之辨正}

胡宏《知言》原文 :

天命之謂性。性, 天下之大本也。堯、舜、禹、湯、文王、仲 尼六君子先後相詔, 必日心而不曰性, 何也? 日：心也者, 知 天地, 宰萬物, 以成性者也。六君子, 盡心者也, 故能立天下 之大本, 人至于今賴焉。不然, 異端并作, 物從其類而瓜分, 孰能一之。16

本文就是胡宏的一套本體工夫的論述。胡宏本文之文義頗有跳躍, 然而參看《知言》中的其它文字, 亦頗能互為發皇, 而見出胡宏所談確 實是守在儒家道德意識本位的本體論哲學，以及貫徹意志以實踐之工夫 論哲學。本文強調君子必「盡心」而後「成性」「「成性」者成其「天命 之性」「「盡心」即是工夫實踐, 儒者未有不要求做工夫, 孟子之言「盡 心」, 即是掌握本體工夫的根本意旨, 儒者之本則為聖人境界之達至, 故 而是做工夫的目的。《易傳》首言「成性」, 宋儒張載亦言「成性」, 並配 合「氣質之性」及「天地之性」之架構以說「善反之天地之性成焉」, 這 其實是一個既正常又普通的儒學命題，從主體修養以至境界完成的兩段 概念。在胡宏之處並非特別地提出了什麼創造性的哲學意見, 只是朱喜 卻創造性地誤解了。針對上段文字朱喜之批評意見如下 :

朱子日:「以成性者也, 此句可疑。欲作「而統性情也」何如? 張南軒日：「統」字亦恐未安。欲作「而主性情」, 何如? 朱子

16 《胡宏集・附錄一・宋朱喜胡子知言疑義》胡宏著, 吴仁華點校, 中華書局 1983 年 5 月出 版。以下《知言疑義》之討論皆引自此, 不再加注 
日：所改「主」字極有功。然凡言刪改者, 亦且是私寀講貫議 論, 以為當如此耳, 未可遽塗其本編也。何如? 又案：孟子盡 心之意, 正謂私意脫落, 眾理貫通, 盡得此心無盡之體, 而自 是擴充, 則可以即事物而無不盡其全體之用焉耳。但人雖能盡 得此體, 然存養不熟, 而于事物之間一有所蔽, 則或有不得盡 其用者。故孟子既言盡心知性, 又言存心養性, 蓋欲此體常存 而即事即物各用其極, 無有不盡云爾。以大學之序言之, 則盡 心知性者, 致知格物之事; 存心養性者, 誠意正心之事; 而天 嘉不武, 修身以俟之者, 修身以下之事也。此其次序甚明, 皆 學者之事也。然程子「盡心知性, 不假存養, 其唯聖人乎」者, 蓋唯聖人則合下盡得此體, 而用處自然無所不盡, 中間更不須 下存養擴充節次工夫。然程子之意, 亦指夫始條理者而為言, 非便以盡心二字就功用上說也。今觀此書之言盡心, 大抵皆就 功用上說, 又便以為聖人之事, 船疑未安。( 朱子自注: 舊說未 明, 今別改定如此。）……朱子曰：論心必兼性情, 然後語意 完備。若疑與所設問不相應, 而「者也」二字亦有未安, 則某 欲別下語云：「性固天下之大本，而情亦天下之達道也，二者不 能相無。而心也者, 知天地, 宰萬物, 而主性情者也。六君子 者惟盡其心, 故能立天下之大本, 行天下之達道, 人至于今賴 焉」云云。不知更有病否? 若所謂「由盡其心」者, 則鲛恐太 狹, 不見程子所謂「不假存養」之意。

朱喜此處之批評有㒳條路線, 其一為對「心以成性」說的批評, 這是存有論的問題。其二為對孟子「盡心」概念使用的批評, 這是工 夫次第論的問題。首先, 胡宏論於 $「$ 盡心成性」者本是一套本體、工 夫、境界論的陳述, 正是一個動態的活動歷程的完成, 朱喜則不顧此 
義, 一見論 $「$ 心」即出言 $「$ 心統性情」或 $「$ 心主性情」, 這是對實踐主 體的存有論分析, 是主體的存在結構的抽象分析, 而不是主體的實踐 活動的展現歷程。「盡心成性」是一動態歷程的展現，「心統性情」是 一靜態的存在架構, 兩者問題根本不同, 以之批評胡宏是不必要的。 其次, 朱喜以「格物致知說」合併 $「$ 涵養先於察識說」的工夫次第論 對胡宏說孟子 $\ulcorner$ 盡心」的批評。朱喜以《大學》之格物致知是知識學 習的活動, 並以此詮釋孟子的盡心知性, 以《大學》的誠意正心是日 常生活中的道德意識之涵養的活動, 並以此說孟子的存心養性, 如此 則將《大學》一書從為學次第上解讀了, 此說亦自成一理, 雖不太符 合孟子之本意。朱喜並指出程子言於盡心知性不假存養者是就聖人境 界說的, 此說牟先生指出是伊川文字 ${ }^{17}$, 朱喜認為伊川所指之聖人境界 者或可直言盡心而不假存養, 但是就一般人而言的盡心必應是《大學》 的知識義的盡心知性, 而這又應該配合涵養義的存心養性, 從而建立 一套下學上達的工夫次第系統。即首先有一「盡心知性知天」的 $「$ 格 物致知」的知識累積的階段, 接著有一「存心養性事天」的「誠意正 心」的自我培養階段, 最後才有「修齊治平」的實功實業的實踐階段。 朱喜把盡心連著知性來看待, 而知性又即是「格物致知」的《大學》 初步階段, 尚未進至「誠意正心」之存心養性之涵養階段, 更未進入 真正「修齊治平」之社會實踐階段，故而以胡宏之「盡心」即欲立天 下之大本者是語意狹迫。即朱喜不以為胡宏之言盡心是可信賴的, 因 為少了涵養。

朱喜論於胡宏的意見可以不必重視, 因為我們不可能從朱喜的誤解 中來認識胡宏, 但是這其中朱喜自己的陳述部份, 就是呈現朱喜理論的 重要材料, 是我們認識朱喜哲學的進路。

17 牟宗三先生的討論見於前引《心體與性體・二》頁 452 


\section{（二）「天理人欲」的本體工夫論與「性善論」的本體論 之辩正}

《知言疑義》中的胡宏原文：

$「$ 天理人欲, 同體而異用, 同行而異情。進修君子, 宜深別焉！」

這一段文字在朱喜的批評中是以胡宏不辨天理與人欲而批評之, 但 這卻不是胡宏的本意。關鍵在於這個「體」字被朱喜以「本體」視之, 其實它只是指得一件「事情」而已。牟宗三先生將同體異用的「體」解 釋為「事體」而非本體 ${ }^{18}$, 這也正是筆者的理解。胡宏的這一段文字是 頗有辯證性的, 當我們並觀胡宏此文及其它文字時, 便可以較準確地疏 理此文之文義，這一段文字和程影的「天下善惡皆天理」的思路是相同 的, 是哲學家在實做工夫中, 在主體的心境已經提升後, 對於人事現象 的體會之語, 體會之語有感性的因素, 因此在描寫時的思維路徑會特別 曲折, 但是因為它有實做工夫的基礎, 因此亦是一理性思辨後的結果, 因此亦得以理性的思路予以清哳地言說, 依胡宏之意:「那些表現在社會 現象中的被稱為合天理或不合天理的事件, 其實都是同一件事, 同一件 事中有人依循天理處理它, 有人依循人欲處理它, 有人處理得合乎天理, 有人處理得充滿人欲, 都是同一件事情, 不同人的處理使它顯現差異的 情態, 這一切都只是因為君子當下的心念之別所造成的, 進德修業的君 子實應深自反省。」胡宏對生活事件的具體善惡現象做反思, 言語之軌 跡偏險, 卻無意新發議論, 對於天理是善的、人欲是惡的傳統儒學基本 立場是沒有改變的。但是, 朱喜在解讀此章時卻認為胡宏把天理人欲混

18 参見牟先生言: 「『同體』者『同一事體』之謂, 非同一本體也。『異用』是異其表現之用, 非體用之用。 『同行』者, 同一事行也。『異情』者, 異其情實也。』觶與性體. 二》頁 454 。 
為一談。實際上, 胡宏並非如朱喜所說, 參考他的另一些文字即知其意, 下文中以道存於飲食男女之事的意見, 涉及到五峰的天理、人欲之辨的 問題, 參見 :

夫婦之道, 人醜之矣, 以淫欲為事也。聖人則安之者, 以保合 為義也。接而知有禮焉, 交而知有道焉, 惟敬者為能守而弗失 也。《語》日「樂而不淫」, 則得性命之正矣。謂之淫欲者, 非 婳庸人而何? ${ }^{19}$

本文說同樣是夫婦之道一件事, 一般人以之為只是淫欲, 因而避談 之。但是聖人以保合為義, 也就以之為傳宗接代的有益身心的事, 胡宏 說這就是從天理的途徑對待這件事 ; 至於有些男女對於夫婦之道僅視之 為得以行淫欲之事, 這就是從人欲的途徑在對待此事。同樣是夫婦之間 的事, 卻有天理人欲之別, 因此這個分別只是在說各人的不同對待態度 而已, 而並不是在為天理與人欲下定義的事。顯然, 胡宏是在生活層次 中使用天理、人欲的概念, 而不是在做本體論的善惡問題的討論, 更不 是在做存有論的概念定義之事, 胡宏既是在實踐中使用概念, 而非在學 問上定義概念, 因此並沒有違反天理與人欲之善惡有別的一般使用義, 參見胡宏以下文字更為明白 :

人欲盛, 則於天理昏。理素明, 則無欲矣。處富貴乎? 與天地同 其通。處貧賤乎? 與天地同其否。安死順生, 與天地同其變, 又 何宫室、妻妾、衣服、飲食、存亡、得喪而以介意乎 ? ${ }^{20}$

本文明指以天理、人欲為對立之概念,$\ulcorner$ 人欲盛, 則於天理昏。理素 明, 則無欲矣。」本文中胡宏仍是提出一本體工夫的實踐要求, 要求與

\footnotetext{
19 《胡宏集・知言・除陽》頁 7 。

20 《胡宏集・知言・紛華》頁 24 。
} 
天地同其通, 其實即是循天理之意; 而不應以「宮室、妻妾、衣服、飲 食、存亡、得㕵」為意, 其實即是去人欲之意。可見天理、人欲之辨本 就是一極明白淺顯的儒學議題, 從價值面說, 天理、人欲在善惡上是對 立的概念, 但從現實面說, 人欲就是在講日常生活, 只要不過度即非惡 事, 故非與天理有別的概念, 反而是天理要落實下來的具體事務。不過, 人欲一旦過度, 即是為惡, 則須 $「$ 存天理去人欲 $\lrcorner \circ$ 胡宏使用天理、人欲 討論問題的概念又見下文：

天理人欲, 莫明辨於春秋。聖人教人清人欲, 復天理, 莫深切於 春秋。21

本文即是就天理人欲之辨在價值意識的應用上, 說春秋著作的目的 就是聖人教人清人欲復天理的, 本文之天理人欲的概念應用, 明確地為 一善一惡的對立性概念, 顯見胡宏並未有特殊別異於宋儒的使用義。以 下是以人欲概念為惡的使用意義 :

生本無可好, 人之所以好生者, 以欲也; 死本無可恶, 人之所以 惡死者, 亦以欲也。生, 求稱其欲; 死, 懼失其欲。衝衝天地之 閒, 莫不以欲為事, 而心學不傳矣。22

本文主張人若溺於人欲則心學不傳, 而心學即是五峰的本體工夫之 學, 以心為實踐主宰之地, 故而要求做工夫之學即是心學, 說心學即是 要求實踐, 即是以天理之價值意識以為主體心行之標的而為實踐之目 標, 實踐即實踐價值理想, 追求價值理想時即不把個人生死置於第一, 仍重視個人生死即是人欲之需求, 即是悖天理之行為。

21 《胡宏集・知言・ 一氧》頁 28 。

22 《胡宏集・知言・文王》頁 18 。 
總結以上與天理人欲概念相關的胡宏文句, 顯見胡宏於此一天理與 人欲之辨的基本立場即是與朱喜相同的, 亦是與一般儒者的概念使用相 同的, 只有在涉及三教辯證的價值觀討論中, 為強調天理需落實於事物 之中, 而有不以夫婦之事為淫慾之說似有不同, 而此說實非主張天理人 欲不分之說, 此說本就是以天理下貫人事而要求正人事循天理之意, 該 文之說人欲就只是在說對日用常行之事的對待態度, 說同一件事有天理 人欲的兩種對待態度, 並不是在談價值意識的本體論以至於將天理人欲 混而為一。

會有胡宏不分天理人欲的善惡之說者, 完全是來自於朱喜在《知言 疑義》中的誤解。朱喜針對 $「$ 天理人欲, 同體而異用, 同行而異情。進 修君子, 宜深別焉！」一文之意見如下：

朱子曰: 某案此章亦性無善惡之意, 與「好惡, 性也」一章相類, 似恐未安。盖天理莫知其所始, 其在人, 則生而有之矣。人欲者, 梏于形, 雜于氣, 狃于習, 亂于情, 而後有者也。然既有而人莫 之辨也, 于是乎有同事而異行者焉, 有同行而異情者焉, 君子不 可以不察也。然非有以立乎其本, 則二者之幾, 微暧萬變, 夫孰 能別之! 今以天理人欲混為一區, 恐未允當。……朱子曰: 再詳 此論, 胡子之言, 蓋欲人于天理中揀別得人欲, 又于人欲中便見 得天理, 其意甚切。然不免有病者, 蓋既謂之同體, 則上面便著 $\ulcorner$ 人欲」二字不得。此是義理本原極精微處, 不可少差。試更子 細玩索, 當見本體實然只一天理, 更無人欲, 故聖人只說「克已 復禮」, 教人實下工夫, 去卻人欲, 便是天理, 未嘗教人求識天 理于人欲泊沒中也。若不能㝠下工夫, 去卻人欲, 則雖就此識得 未嘗離之天理, 亦安所用乎? 
朱喜對此文之討論有兩段, 前段批評胡宏之語是「性無善惡」, 後段 批評胡宏之語就工夫理論之實踐而言是無用的。首先, 就前段言, 朱喜 可以接受 $「$ 同事而異行」與 $\ulcorner$ 同行而異情」之說, 但不能接受 $\ulcorner$ 同體而 異行」之說, 因為論於「體」者即本體也, 本體上容不下人欲而是只能 有天理, 因此胡宏於「體」上同說人欲天理的說法即是「性無善惡論」 者, 這是朱喜把胡宏言於「同體」之「事體義」者誤以為「本體義」而 致生之誤解, 以及不必要之批評。

其次, 就後段言, 儒家本位的道體義之天理概念當然是純善無惡的, 此中無絲毫人欲在, 因為它本來就說得是天道, 而天道下貫人心, 因此 人性中亦有此一天理, 即得謂為性善, 只因人性有形氣之限制, 即有人 欲出現, 故而人生之天理不易全顯, 而做工夫的目的即是要彰顯此一天 理, 即是要去除此一人欲。這就是朱喜的思路, 在這個思路中進行的知 識架構毫無疑問地是正確的, 但是這是學問上的概念定義, 至於在實踐 中的概念使用就又是另一回事了。在實踐中使用概念則已進入感受體㙋 的情境中, 此時只以习鑽人心 、險峻情緒為得其要領, 必欲在千迴百折 中始終貞守主旨者才算是達到實踐的目的, 因此胡宏說天理人欲都在同 一件事中以要求君子自作進退之話語, 目的就是警凛人心, 而朱喜則錯 解其意, 以為胡宏之說正不能讓人好好實做工夫 $:\ulcorner$ 故聖人只說『克已復 禮』, 教人實下工夫, 去卻人欲, 便是天理, 未嘗教人求識天理于人欲汨 沒中也。若不能實下工夫, 去卻人欲, 則雖就此識得未嘗離之天理, 亦 安所用乎? 」實際上胡宏之說即已是教人實下工夫, 朱喜卻以為胡宏是 要大家在知識認識上認識天理人欲是同一件事, 是同在道體上的事, 是 天理的道體中有人欲在, 這當然是錯解。胡宏是工夫境界地說, 朱喜是 知識認識地說, 胡宏的天理人欲在概念定義的意旨上當然還是兩件事, 只是在現實的工夫操作中它就是落實在同一件事情上的主體自己的心念 
的非此即彼上, 因此是同一事件的不同心念, 因此是要大家在心念上好 好做實功, 亦即是朱喜講的「實下工夫」, 若不下工夫則當下這件事情就 都是人欲橫流了。事實上朱喜論知識時即論知識, 說實踐時即說實踐, 而胡宏則是在知識使用中言說實踐, 因此必將籠罩兩端, 朱喜思路與胡 宏不同，致生錯解，這卻並非胡宏有失誤之處。

\section{（三）「好惡性也」的本體工夫論與「性善論」的本體論 之辨正}

胡宏《知言》原文 :

$\ulcorner$ 好惡, 性也。小人好惡以已, 君子好惡以道。察乎此, 則天理 人欲可知。」

胡宏此文重點在好惡以已或以道, 以道則顯天理, 以已則現人欲, 觀其以己或以道, 即能察知此人是生活在天理的脈絡上, 還是人欲的汨 沒中。因此整句話就是在要求存天理去人欲的意思。至於 「好惡, 性也」, 牟宗三先生解為好善惡惡之善性主體之性, 亦即以善性為主宰則此心自 能當好則好當惡則惡, 若人心蒙於私欲而以已私出焉時, 則君子應彰顯 天理而以天道出焉。不過, 朱喜卻將上文解為人有以天理好惡, 亦有以 人欲好惡者, 而這都是人性中所含具者, 因此以胡宏之說為「性無善惡」 者。光從原文字義上說, 兩解似皆可, 只能說是胡宏自己用語不精準所 致, 雖然比較並觀於胡宏之其它文字, 則較能確定牟先生之解為是。事 實上, 胡宏話語的重點只是要人分辨君子小人之別, 要人存天理去人欲, 要人知道自己正在天理路上還是人欲途中, 所以這是一個做工夫的要求 語, 而不是一個說工夫理論的知識語, 因此胡宏文義中並無一個本體論 或人性論意義的 $\ulcorner$ 性無善惡說」, 這只是朱喜的批評意見, 參見朱喜言： 
朱子日：案此章即性無善惡之意。若果如是, 則性但有好惡, 而無善惡之別矣！「君子好惡以道」, 是性外有道也。「察乎此, 則天理人欲可知」, 是天理人欲同時并有, 無先後賓主之別也。 然則所謂「天生丞民, 有物有則; 民之秉彝, 好是懿德」者, 果何謂乎? 龜山楊子日：「天命之謂性, 人欲非性也。」卻是此 語直截。而胡子非之, 誤矣。……朱子日：好惡固性之所有, 然直謂之性則不可。盖好惡, 物也; 好善而惡惡, 物之則也。 有物必有則, 是所謂「形色, 天性」也。今欲語性, 乃舉物而 遺則, 恐未得為無害也。

朱喜在前文及本文皆批評胡宏之說為「性無善惡說」, 儒家哲學論 於價值義的本體論時一定是有善無惡的，一旦流入「性無善惡說」就 絕對是錯誤的, 因此針對各種不同文本作詮解時, 必須要追究該哲學 命題是在談什麼問題以及怎麼談的, 而不能過度簡化地批評他人之說 即是「性無善惡」。儒學史上除了荀子在經驗現象層面上說人性是惡之 外, 自《大學》、《中庸》、《易傳》至宋儒以降, 多有明確主張一個絕 對至善的天道本體及性善的人性本體之說者, 最多是對於經驗現象的 $\ulcorner$ 惡」提出「氣質之性」的「過度為惡」之解說體系者如張載, 又或 是就實際的社會現象而說「善惡皆天理而惡非根本惡」之說者如程影, 然此二型皆仍是「性善論」型。因此對於朱喜而言, 知識上論於人性 必是善的, 論於天道必是善的, 若有論於「有善有惡」者則為揚雄、 王充之流, 甚至是道佛之徒, 朱喜必會指責之。胡宏既然是儒者, 因 此義理上當然不能渾淪籠統地說「性無善惡」之說。朱喜引「天生丞 民, 有物有則 ; 民之秉膆, 好是懿德。」而言性善, 又引「形色天性 也」而言性善, 這些都是儒家論說天道本體及人性本體的性善說的典 範, 無可置疑, 亦不能反對, 因為這就是儒學道德意識的根本型態定 
位, 儒家價值立場就是這一套, 只是胡宏所說卻全不是朱喜所指控的 意思。

（四）「世俗酬醮」的本體工夫論與「下學上達」的工夫 次第論之辨正

胡宏《知言》原文 :

心無不在, 本天道變化, 為世俗酬酢, 参天地, 備萬物。人之為 道, 至大也, 至善也。放而不知求, 耳聞目見為已蔽, 父子夫婦 為已累, 衣装敛食為已欲, 既失其本矣, 猶皆日我有知, 論事之 是非, 方人之短長, 终不知其陷溺者, 悲夫! 故孟子日：「學問 之道無他, 求其放心而已矣。」

胡宏此文是談工夫論的問題, 說 $「$ 心無不在」, 是說心的作用是沒有 一時或息的, 更沒有一事不可面對的, 若體貼於天道性命, 則可面對萬 事萬物而處理妥當。因此一個可以體貼天道而行道之人, 他的影響力所 及是極為廣大的, 也是絕對至善的。只是人性一般都還會受到世俗中事 務的羈絆, 而未能依天道而行, 更有甚者以物照的率引而強為合理化藉 口, 這就犯了更嚴重的錯誤了。因此學者應該時時刻刻提起自己的心念, 依道而行, 這就是孟子說求放心之用意。

胡宏之論, 淺顯平實, 並無任何特出創見, 並且還預設了許多並 未說出的基本命題, 例如必須是有一個天道, 且天道是善的, 以及確 實有一個性善的人性, 並且人性中也確實存在著氣秉之惡, 以至於有 可能流於物慾而為己蔽之累, 這些是胡宏此文中所預設而未談出的, 卻也未必在胡宏之他文中被明確強調的, 但是這些都是儒學義理的必 然格局, 胡宏沒有反對, 更不會不解, 只是這些都已經在前人之論述 
中出現, 因此他也無需再為論述。他所關心的是實踐的問題, 他在重 述孟子對求放心工夫的想法。求放心工夫勢必預設性善論, 性善論是 孟子為儒學義理定出的核心價值命題, 做君子的事業在孔子處是以道 德教條的姿態在要求他的學生的, 孟子性善論就是要給這個要求一個 根據的, 因為是性善, 所以人人必須自我要求做工夫以成為君子, 成 為君子就是要做工夫, 這是因為人心通常會有所放失而滑落, 故而應 做工夫。孟子將做工夫的格式說為求放心, 因為本心是性善的, 如有 放失, 只要回復之即可, 故是求放心。求放心且是人人皆可行, 以及 應該行者, 這是孟子接續孔子學說所進行的理論建構。胡宏沒有進行 這樣的討論, 僅僅是使用之而重述之。朱喜則確知孟子學說之成立必 然要基於性善論, 因此不僅自己建立性善論, 也批評任何 $「$ 性無善惡」 之學說, 即就胡宏上文言, 因胡宏說了人道至善, 故而受到朱喜肯定, 認為胡宏最終還是必須是這個性善論的立場。但朱喜仍另就工夫論而 批評此文言之過高, 實際上無法落實, 其言 :

朱子日：「人之為道, 至善也, 至大也」, 此說甚善。若性果無 善惡, 則何以能若是邪? ……朱子曰: 某詳此論性甚善。但明 道所謂「惡亦不可不謂之性」, 是說氣禀之性, 觀上下文可 見。……某又看此章云: 「本天道變化, 為世俗酬酢」, 疑「世 俗」字有病, 猶釋子之謂父母家為俗家也。改作「日用」字如 何? ……某又細看, 雖改此字, 亦為未安, 盖此雨向大意自有 病。埾人下學而上達, 盡日用酬酢之理, 而天道變化行乎其中 爾。若有心要本天道以應人事, 則胸次先横了一物, 臨事之際, 著意將來把持作用, 而天人之際终不合矣。大抵自謝子以來,

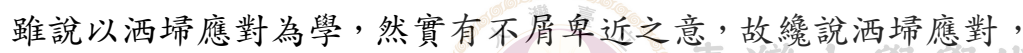


便須急作精義入神意思, 想像主張, 惟恐其滞于小也。如為朱 子發說《論語》, 乃云「聖門學者, 敢以天自處」, 皆是此箇意 思。恐不免有病也!

本文有兩個議題, 其一為性善論議題, 其二為談工夫的用語問題。朱 喜對胡宏之前說批評為「性無善惡」, 但對此說則謂胡宏言之甚善, 亦即 是認為胡宏此說即已非「性無善惡」之主張矣。導致朱喜這樣不同的評價, 是因為胡宏在不同的地方談不同的哲學問題所致。朱喜論說價值義的道體 與性體, 那自需是絕對至善的, 至少是儒學之大宗皆持此義, 但是胡宏卻 都說得是工夫, 說工夫從現實上說來時則有天理、人欲、君子、小人之分, 而這都是氣質之蔽之收攝不收攝的差別所致, 因此要強調的是主體要收 攝、要求放心, 要即在流於惡後尚做工夫, 因此用語多需同時照管善惡二 端, 但這並不表示他在渾淪性與天道之善惡價值。至於此文, 胡宏非從天 理、人欲、君子、小人之辨上討論, 而是直下言說君子體天道為至善之工 夫，因此被朱喜引為人性論及天道論問題上的性善論立場。

就談工夫的用語問題而言，朱喜首先改胡宏之「世俗」為「日用」 而攻其有釋氏幻滅世間的立場，筆者認為朱喜此一改動實是 $「$ 草木皆兵」 的做法, 概念的使用以其脈絡及宗旨而定意義, 四需以學派之習用而分 屬性, 更重要的是, 胡宏以世俗酬酢為本天道變化之說, 正與其言於 $\ulcorner$ 天 理人欲同體異用同行異情」之意旨相同, 即在世俗酬酢中為君子之道, 意旨簡潔, 並無悖理, 朱喜改「世俗」為「日用」, 實是將社會事業是 $\ulcorner$ 理 想的目的」還是 $\ulcorner$ 虛幻的俗物」的哲學問題搬上來討論, 以為胡宏講 $「 世$ 俗」就是偏向佛教的虛妄世間的立場。胡宏䦕佛實不遺餘力, 朱喜實不 應以「世俗」二字之使用, 即指胡宏有以社會事業為幻妄之佛教立場, 這是此句的朱喜批評的路線之一。 
其次, 朱喜又批評胡宏此說有好高䯂遠無處落實之弊, 問題只在 胡宏言於「本天道變化」一辭, 朱喜認為做工夫就是要從下學做起, 而天道自在其中, 若只把天道騰口說說, 其實正是著意把持, 正中孟 子之言於忘、助之過, 實是無有實心, 就像自謝上蔡以來, 都有不屑 下學之病。朱喜此一批評與他的工夫理論重視平日培養的思路是相同 的, 平日培養的工夫就是在日用平常之間培養良善的本心, 此一行動 自然即是天道在人的落實與顯現, 這就是朱喜一直要強調的工夫次第 的要點。說工夫要在日用常行中培養這當然是正確的, 說日用常行中 的酬酢即是本著天道變化的應用這也還是正確的, 朱喜卻以胡宏說本 天道變化以為日用常行的說法是著意胸中, 不是 $\ulcorner$ 必有事焉」, 而是 有「助長之」之病, 因此認定胡宏與謝上蔡一樣, 都在言於下學之事 時有不屑之意, 亦即朱喜認為他們都不願意真正在日用常行中下學地 實踐, 而是虛妄地高舉天道, 假意胸中, 實成執障。實際上胡宏說心 是強調要實做工夫, 胡宏說天道是要說工夫是必然可行的, 朱喜卻把 胡宏說天道的論點當作是騰口說說的虛話, 是一種心態的陳述, 故而 是一多餘的執著, 表示實踐者心口不一, 有口無心, 心實不到。這是 對於現實上的實踐成效的個人批評, 其實是和理論無關的。理論上不 論是強調「行道就在下學中」, 還是主張「要本天道來行下學之道」, 這都是理論層次的問題, 這都仍與現實實踐是兩回事, 具體經驗中被 朱喜所批評的上蔡、胡宏等人是否確有不重視下學的毛病, 此事不得 而知, 但是就理論陳述而言, 胡宏此說並沒有朱喜所批評的意思。朱 喜沒有理由把現實的觀感和理論的陳述混在一起, 更重要的是, 即便 胡宏、謝上蔡等真有不重下學之病, 也不等於胡宏此說是不重下學的 論述。 
（五）「不與惡對之性」的本體論、「心無生死」的境界 印證與「性善論」的本體論、「輪迥觀」的宇宙論 之辩正

以下有兩段胡宏的文字被朱喜合併地批評, 胡宏《知言》第一文:

或問性。日：「性也者, 天地之所以立也。」曰:「然則孟軛氏、 荀卿氏、楊雄氏之以善惡言性也, 非與? 日源性也者, 天地鬼 神之奥也，善不足以言之，況恶乎哉!」或又日：「何謂也？」日：

$「$ 某聞之先君子曰: 『孟子所以獨出諸需之表者, 以其知性也。』 某請曰:『何謂也?』先君子日:『孟子之道性善云者, 歎美之解, 不與惡對也。』」

胡宏說性為「天地之所以立也」, 又說「善不足以言之」, 又說孟 子之言性善是 $\ulcorner$ 不與惡對」, 以上諸說並立, 顯然極需澄清。首先, 就 儒學立場而言, 若論於終極價值之性, 當然還是善的, 且是純粹絕對 的至善, 故而「不與惡對」, 這是價值意識的本體論的討論。其次, 這 個本體論層次的性善論的討論, 放在生活實踐的感受中而言, 也可以 強調它不是相對於社會現象中之小善小惡之善, 故曰 $「$ 善不足以言之, 況惡乎哉！」。再者, 亦可以討論性概念之抽象定義, 此時亦不論其善 惡, 而是要談性本體的超越、絕對、遍在諸義, 如本文所說的「天地 之所以立也」的說法即是其中之一, 這並不是說它不是善, 只是這不 是一個論於善惡的價值本體的問題, 而是以性概念作為一個抽象對象 來討論的存有論問題, 朱喜論於 $「$ 心統性情」時亦即此一思路下之哲 學問題。

就胡宏此處的思路言，胡宏先已確定了「性也者天地之所以立也」 的立場, 這是存有論進路地說, 且是預設在性善論的本體論立場上所說 
的 ; 胡宏又為回應哲學史上種種說善說惡的性論立場, 由現實人生的感 受而說這個性是 $「$ 善不足以言之」, 這是就人生體驗而說的, 指對性的討 論不能執著於現實生活上的簡單善惡, 程影即多能在現實生活中體會善 惡而說話的, 其言 : 「天下善惡皆天理。謂之惡者, 非本惡, 但或過或不 及。」 23 , 既然惡者非本惡, 即是說性善之義, 至於天下善惡皆天理, 則就是在說處理人間世事的有德君子應該以天理之善意對待一切百姓人 民的善惡諸行, 因為人民的惡行只是過或不及, 人民的本性還是善的, 這些善惡實為社會現象中的小格局的事件而已，程影善於調理之，而胡 宏即亦為在此一思路下的對性之善惡問題的討論, 故而說「善不足以言 之, 況惡乎哉！」。至於有見於社會經驗中的善惡現象因而言說人性之為 惡者如荀子、及言說善惡渾者如揚雄, 這並非胡宏的立場。胡宏否定了 荀子及揚雄的言性, 那麼對孟子的性善說呢? 胡宏此處以其父之「不與 惡對」說之, 但是卻說只是「嘆美之辭」。實則, $「$ 不與惡對」之善即已 是性體本然意義之善, 此即與朱喜關心的問題一致了, 然而朱喜還是認 為胡宏此說是主張 $「$ 性無善惡」, 這當然是因為胡宏一句 $「$ 善不足以言之」 所致的了, 以上辨之。

下文是胡宏 《知言》之第二文, 朱喜以為是佛教觀點, 參見胡宏言 : 或問：「心有死生乎？」日：「無生死。」日：「然則人死，其心 安在？」日:「子既知其死矣, 而問安在邪！」或日：「何謂也？」 日:「夫唯不死, 是以知之。又何問焉！」或者未達, 胡子笑日： $\ulcorner$ 甚哉, 子之蔽也! 子無以形觀心, 而以心觀心, 則其知之矣。」

胡宏此段問答文字是境界印證式的語錄體文字, 這一段問答的語言 使用只是在做境界印證, 並不是在作概念定義以及知識陳述, 因此是在

23 《宋元學案・卷十三・明道學案・上》 
處理情境中使用概念, 而不是在知識陳述中界定概念。《莊子》書中充滿 了這樣的文字, 禪宗裏更多得是這類的文字, 這是直接指點人心的操作 活動記錄，而不是哲學命題的概念界定。對於 「心有生死乎？」的問題， 胡宏心裏想的是人活著就是要時時刻刻提起善念做工夫, 不可一刻停 息, 故而說 $\ulcorner$ 無生死」。然而問者卻是在問一個自然生命意義的人的死亡 問題, 問此時有心乎? 這個問題對道德實踐而言是毫不相干的問題, 人 死了自然就不能做工夫了, 那還用問嗎? 所以胡宏說「子既知其死矣, 而問安在邪！」, 但是問者不解, 繼續追問何義? 胡宏就說, 最重要的心 可不可以做工夫, 只要人是活著, 就一定可以做工夫, 故而活著的時候 人心必是一直在運作中的, 故而是無生死, 無生死不是人無自然意義的 生死, 這是以形觀心, 無生死是人的道德意識應該無一刻或停, 這才是 以心觀心, 自然意義的生死問題有什麼好問的, 又不是道教言不死神仙 的問題, 或是佛教言永恆輪迴的問題, 既然是儒者, 就只要關心活著的 時候如何提起善念做工夫的問題就好了。這就是胡宏此文的整個思路歷 程, 這就是境界印證的語錄文字, 文字是活動的紀錄, 過程中胡宏想要 操作問者的心理狀態, 然而失敗了, 如果成功, 就是印證了, 因為失敗 了所以只好笑笑地說 : $\ulcorner$ 甚哉, 子之蔽也! 子無以形觀心, 而以心觀心, 則其知之矣。」。這樣的文字朱喜卻是完全誤解的, 並且批評其說為佛教 輪迴之說。以下即是針對前述兩段胡宏文字的朱喜的批評：

朱子曰: 「性無善惡」「心無死生」兩章, 似皆有病。性無善惡, 前此論之已詳; 心無死生, 則幾于釋氏輪迴之說矣。天地生物, 人得其秀而最靈。所謂心者, 乃虚霝知覺之性, 猶耳目之有見聞 爾。在天地則通古今而無成壞, 在人物則隨形氣而有始終。知其 理一而分殊, 則又何必為是心無生死之說, 以駭學者之聽乎! 
朱喜顯然直接把這一段文字當作自然生命的有無生死問題來認知, 既然胡宏主張無生死, 那就是佛教輪迴說的意思了, 朱喜因而展開理氣 論架構的生死觀論述, 實是多餘。可見朱喜一方面是不了解而誤解, 另 方面是進入了宇宙論問題的討論。

\section{（六）「天命所有」的本體工夫論與「性善論」的本體論 之辩正}

胡宏《知言》原文 :

凡天命所有而眾人有之者, 聖人皆有之。人以情為有累也, 聖人 不去情。人以才為有害也, 聖人不病才。人以欲為不善也, 聖人 不絕欲。人以術為傷德也, 聖人不菓術。人以憂為非達也, 聖人 不忘憂。人以怨為非弘也, 聖人不釋怨。然則何以別于眾人乎? 聖人發而中節, 而眾人不中節也。中節者為是, 不中節者為非。 挾是而行則為正, 摤非而行則為邪。正者為善, 邪者為惡。而世 儒乃以善惡言性, 邀乎遼哉!

胡宏此文正是程影學思的舖陳展現, 強調就在社會現實的緊張狀 態中當下直接做起道德事業, 故而「不去情、不病才、不絕欲、不棄 術、不忘憂、不釋怨」, 這些事件都是在現實中崇德廣業、興國理民者 的必為之事, 而正人君子在現實中面對種種相對善惡諸事之時, 即是 直接做工夫之時, 即是他提起道德意志而貫徹之的時候, 如若不然即 落入小人為惡之行徑了。此時是非善惡皆在一事之中，行於「是、正」 則善, 行於「非、邪」則惡, 君子小人也就在此有別了, 故而是天理 人欲同行異情。由此可見社會現象的表面善惡是一時的, 人心的轉變 才是決定事件的善惡的關鍵，因此過於單純地以夫之為善或為惡的現 
象以說人性之善惡的斷言是不準確的。胡宏此言並非在人性論的普遍 定義層次上論善惡, 而是在現實中體會具體的個人行為的意義, 而認 為這是隨時會改變的情況, 故而不能隨現象的狀態就斷言人性是善或 惡的, 在現實中表現出來的善惡與根本人性的善惡問題相差是很大 的。朱喜對胡宏此說則又認定是「性無善惡」之意：

朱子曰: 「聖人發而中節, 故為善。眾人發不中節, 故為惡。世儒 乃以善惡言性, 邀乎遼哉! 」此亦性無善惡之意。然不知所中之節, 聖人所自為邪? 將性有之邪? 謂聖人所自為, 則必無是理。謂性所 固有, 則性之本善也明矣。……朱子曰: 某詳此段, 不可盡刪。但 自「聖人發而中節」以下刪去, 而以一言斷之云：「亦日天理人欲 之不同爾！」……朱子曰: 某觀此論, 切中淺婳之病, 謹已刪去訖。

朱喜之所以批評胡宏此言為「性無善惡說」者, 是以為胡宏主張 了性中所發有善有惡, 故而又是一個性無善惡說。然而胡宏所言實為 現象中的經驗陳述, 而朱喜關心的是純粹的人性本質問題, 故而以胡 宏之用語即是「性無善惡說」。然後朱喜又指出胡宏既有聖人之發而中 節之事, 則所中之節豈非即是性善之義, 因此批評胡宏之論述義理不 清, 認為胡宏自己根本就預設了性善說而不自知。因此要求「聖人發 而中節」一段以下都應刪去。朱喜對胡宏之批評議論是以他自己的問 題意識而提出的, 雖對胡宏文義有所誤解, 但也反應了他自己的問題 關切以及系統建構。

（七）「盡心」「識仁」的境界印證與「涵養察識」的工夫 次第論之辨正:

以下是胡宏與彪居正在《知言》的一段問答： 
彪居正問 : $「$ 心, 無窮者也, 孟子何以言『盡其心』?」日：「惟 仁者能盡其心。」居正問為仁。日：「欲為仁, 必先識仁之體。」 日：「其體如何？」日：「仁之道，弘大而親切。知者可以一言盡； 不知者, 雖設千萬言, 亦不知也。能者可以一事舉; 不能者, 雖 指千萬事, 亦不能也。」日:「『萬物與我為一』, 可以為仁之體 乎？」日：「子以六尺之軀，若何而能與萬物為一？」日：「身不 能與萬物為一, 心則能矣。」曰: 「人心有百病一死, 天下之物 有一變萬生, 子若何而能與之為一? 」居正羷然而去。他日, 某 問日:「人之所以不仁者, 以放其良心也。以放心求心, 可乎? 」 日:「齊王見牛而不忍殺, 此良心之苗裔, 因利欲之間而見者也。 一有見焉, 操而存之, 存而養之, 養而充之, 以至于大。大而不 已, 與天同矣。此心在人, 其發見之端不同, 要在識之而已。」

本文也是一段境界印證的語錄體文字，而不是為確定概念所進行 的知識陳述語句。本文首先有與居正的一段問答, 後段則是與他人關 於求放心的問答。居正的問題一開始就問得不好，因為任何問題的提 出都預設了問題背後的知識立場, 而胡宏認為居正這個立場是有問題 的, 所以企圖扭轉他的基本認識, 而不是正面地在知識問題上回答, 胡宏不是在進行知識解說, 而是在進行教化操作, 藉由問答而操作居 正的心理狀態, 企圖從而改變他。

居正問心及盡心的問題，一開始就顯示了他把孟子要求君子做工 夫的盡心命題從一個心的客觀存在的量的角度去理解了, 既然量是無 窮的, 則如何盡得了呢? 這當然不是胡宏理解的孟子學說, 事實上這 是一個錯誤的問題, 心在存在上本就只在人身方寸之間, 論其無笨是 說其使用的領域、關懷的事業涵蓋整個可認識的世界而為無窮，而不 是說在存在上遍滿了世界而無窮, 至於這個關懷的領域之無窮地遍在 
之意也不是指的人心之任何時刻皆就任何事件遍在地關切而為無窮, 而是在任何當下的應然的情境中就所應關切的事業的盡其真誠之心意 以為關懷而為無窮。居正問這個盡字如何可能, 這就表示他對這個盡 其真誠以為無笨的工夫意旨不解，因此胡宏以「惟仁者」答之，「仁者」 必是在主體的價值立場上意志堅定者, 堅定即能盡其真誠之心以為無 窮。居正不解, 復問「為仁」, 實即是問「為仁」的方法, 而胡宏又以 程影 識仁」的標準思路答之, 言語上則說為「欲為仁, 必先識仁之 體。」, 胡宏並未展開 $「$ 體」概念的討論，在程影思路中的言於 $「$ 識仁」 者實是一實踐的要求, 以「仁者渾然與物同體」而要求盡其心力以為 家國服務, 關鍵在是否真正提起感同身受的仁德胸懷而真誠致意於服 務, 因此當居正不從落實真誠實踐之路理解，而走向客觀的「仁體」 概念之疑問時, 胡宏便以知者自知、能者必能答之, 意即願意執行者 即能在實踐的歷程中體貼之, 而不願實踐者則永遠不能真知。胡宏至 此已經不太願意從知識解說的脈絡上回答居正的問題了, 但是居正還 是沒有領會胡宏的思路, 而又從知識確定的路線上詢問 $「$ 仁體」是否 為「萬物與我為一」之義? 就此一仁體的概念定義而言, 此一答案自 是不差的, 此即程影及張載原本之所言者, 因此若就知識問答而言, 胡宏即應予以肯定, 然胡宏未予肯定, 這是因為胡宏知道居正之問尚 在外在知識上連結, 而沒有根本的理解, 更沒有在意志上貫徹, 因此 就算在知識上說對了, 實踐上也還是枉然, 因此不肯定居正這個正確 的知識陳述, 遂以知識歧出的路線質問 $\ulcorner$ 六尺之軀如何與物為一? 這個提問本身其實是個錯誤的問題，就像居正一提出的 $「$ 心之無穿如 何盡得」之問題一樣地是錯誤的問題, 提出這個錯誤問題的目的就是 要改變居正想事情的思路, 使從知識認識之路轉向自做工夫的意志鍛 鍊之路上, 然居正依然未能轉頭, 甚至接受了胡宏故意質問的錯誤的 
思考模式, 而接受「身不能盡體萬物」之旨, 遂提出新的主張, 即以心 之意志關懷之說來落實與萬物為一之仁體之意旨, 居正之此說亦無誤, 就像前說以「萬物與我為一」之說之無誤一般, 但是胡宏則關切居正是 否能在知識之認識上進行心意鍛鍊之工夫, 於是以「心百病一死、物 一變萬生」質問之, 這個問法其實也不能否定居正在知識上的以心體 萬物之說的合法性, 這也只是一個刺激, 刺激居正是否真能實在地體 知他所言說的正確知識而能篤實實踐, 然而居正卻是不能回應, 而且 因為察覺胡宏的態度十分孤怪偏詭, 實在不能明白胡宏究竟在作什 麼, 因而驚嚇地離去。此則顯示居正始終在作知識認識的理論活動, 而不能真正用心去稍做實踐體會一番, 而宏則始終只想將之導入貫徹 意志的實踐活動中, 因此兩人愈講愈遠。居正在研究知識, 胡宏在操 作實踐, 居正在馳騁才思詢問定義, 胡宏在洞察人心當下斥喝, 企圖 影響居正的心理狀態而終不可得。

本文後段引出另一段問答, 問者提出以「放心」求心可乎之問, 其根據則是孟子的 $\ulcorner$ 求放心」說, 此義自是清楚, 惟 $\ulcorner$ 以放心求心」之 問頗有暗喻, 不知問者真意為何, 然胡宏亦非就 $「$ 以放心求心」之問作 答, 胡宏是就此心之必應識之而盡之上來強調, 是要求學者必須實踐之 要求語。

以上胡宏的整個接引後學的境界印證之思路, 朱喜是完全沒有接上 的, 朱喜對此前後兩段文字皆展開批評：

朱子日：某案「欲為仁, 必先識仁之體」此語大可疑。觀孔子 答門人問為仁者多矣, 不過以求仁之方告之, 使之從事于此而 自得焉爾, 初不必使先儎仁體也。又「以放心求心」之問甚切, 而所答者反若支離。夫心, 操存舍亡, 間不容息, 知其放而求 之, 則心在是矣。今于已放之心不可操而復存者置不復問, 分 
俟異時見其發于他處, 而後從而操之, 則夫未見之間, 此心遂 成間斷, 無復有用功處。及其見而操之, 則所操者亦發用之一 端耳, 于其本源全體, 未嘗有一日涵養之功, 便欲擴而充之, 與天同大, 愚竅恐無是理也。……朱子曰: 二者誠不可偏廢, 然聖門之教, 詳于持養而略于體察, 與此章之意正相反。學者 審之, 則其得失可見矣。孟子指齊王愛牛之心, 乃是因其所明 而導之, 非以為必如此然後可以求仁也。夫必欲因苗裔而識根 本, 孰若培其根本而聽其枝葉之自茂邪?

朱喜的回應分前後兩段, 前段點出對胡宏識仁說的質疑, 胡宏言識 仁即是程顥之意, 即是直接做工夫之意, 朱喜支離拆解, 先以胡宏之識 仁為知識認識義之識仁, 再以《論語》中未有「識仁體」之說而多為「求 仁之方」之說以談 $「$ 為仁」, 故而批評 $「$ 先識仁體」說之不準確, 認為不 必有「先識仁體」之動作。朱喜之批評既已離了胡宏之意, 這些批評意 見其實就無從檢討了。朱喜對胡宏後段文句之批評重點是放在涵養察識 工夫說上進行的。就胡宏後段對求放心之問答而言, 朱喜認為針對放心 之失就應該進行平日間的培養工夫, 而胡宏的回答是跳過這一段而要在 發於他處時才來操存之, 如此則有失於平日栽培之工夫, 一旦突然要操 存, 必有間斷之弊, 且就此發用一偏之端處來操持, 而無本源之基礎, 則必無法擴充而廣大矣。朱喜之批評顯見他有自己的明確的說工夫的路 數, 他基本上是一個針對學人基本教育的培養次第來思考問題, 學子應 強調平日灑掃應對、格物窮理之培養, 這就是致知、涵養工夫的意旨, 朱喜認為必須經過這樣的歷程, 才有可能在臨事之際做出正確的抉擇, 並能當下承擔重責以追求實踐的完成。朱喜這樣的想法當然是正確的, 但是說工夫的話語本就可以有眾多的思路, 胡宏所言, 是針對任何臨事 之際的當下作為而說的, 但這樣說時並不表示胡宏不主張平日培養的工 
夫, 不表示胡宏不主張學子應多讀書、勤習事以培養之, 胡宏只是在這 一段話中直接討論那個臨事之際的當下抉擇的必然可能以及應該實踐, 說其必然可能就是性善論旨之保證, 說其應該實踐就是提出要求, 本性 上既已可能，實踐上就應著力。臨事之察識可謂是平日之涵養工夫之一 檢證, 也可謂是真正工夫實踐的關鍵。但朱喜認為此處並無可用力之處, 可用力是指不臨事時的平日準備工夫, 這確實是一個重要的思考, 極有 價值, 碰到事情的時候來察識是一種工夫固然沒錯, 但沒事時呢? 可否 有些準備工作呢? 這就是平日涵養之意, 也就是說平日可下手之意。朱 喜又說先聖也是重視前面涵養一段, 是否如此? 這是可以討論及爭辯 的, 此暫不論。就涵養與察識之熟優熟劣而言, 應是兩者皆對且冊須衝 突的。胡宏在臨事一察識的自覺之強調, 當然是工夫落實的關鍵, 而朱 喜在平日可用力之涵養工夫上強調, 這當然是臨事能察識的基礎, 強調 前者或強調後者都不表示否定另一方, 惟朱喜必欲強說胡宏是否定了平 日涵養一方, 因而指責他的說法在臨事察識上無基礎。其實, 胡宏也有 談平日涵養的話：

情一流則難遏, 氧一動則難平。流而後遏, 動而後平, 是以難也。 察而養之于未流, 則不至于用遏矣。察而養之于未動, 則不至于 用平矣。是故察之有素, 則雖篹于物而不惑; 養之有素, 則踓激 于物而不背。《易》日: 「艮其背，不獲其身。行其庭，不見其人。 無各。此之謂也。」 24

胡宏此言極為明顯地就是在講平日涵養的觀點, 雖然他是使用察 養的文字。筆者認為, 朱喜的批評大約是多識於時人俗行浮淺之病而 發的, 他特別痛恨光講察識者之浮談無根又假仁假義的現象。其實,

24 《胡子知言》胡宏此言極為明顯地就是在講平日涵養的觀點, 雖然他是使用察養的文字 
多講平日涵養者也一樣會有作假的, 人們亦會藉由說要涵養反而多有 推諉而臨事逃逸。更重要的是，其實沒有固定的「平日」這一回事， 以年歲算乎? 以職位算乎? 何時才有明確的必須脫離平日而承擔責任 之時機呢? 這就是論說於當下察識的胡宏之說之所以要強調者, 既然 本性是善的, 則就是必有良知良能的, 則任何時刻都必有應為之事, 或必不可為之事, 心念察識一但啟動, 就要自我落實了, 朱喜所謂的 平日涵養的工夫之可以用力之處也就是這裏了, 以察識說工夫, 則大 事小事都可以是一察識一自覺而直下做工夫, 只是觀念上仍可尋思是 否還有平日可以用力培養的機會。以涵養說工夫則強調的是平日的準 備, 對準了隨時要真正承擔的責任而做的平日努力, 可以說平日之時 就已是臨事之際了, 關鍵只在自己的境界高下而有悠遊地處事而為涵 養, 或是機變地斷制而為察識。可以說朱喜強調的是悠遊準備的平日 工夫, 做得好時天下事都是平常小事了。胡宏強調的是實戰演練的當 下實踐工夫, 信任良知良能, 則隨時處理亦無大事了。朱喜後來即說 涵養察識其實嚴分不得, 自己也不再強調兩者間的衝突了 ${ }^{25}$ 。

\section{（八）「性體心用」的本體工夫論與「心統性情」的存有論 之辨正:}

胡宏《知言》原文 :

天地, 聖人之父母 ; 聖人, 天地之子也。有父母則有子矣, 有子 則有父母矣, 此萬物之所以著見, 道之所以名也。非聖人能名道 也, 有是道則有是名也。聖人指明其體日性, 指明其用曰心。性 不能不動, 動則心矣。聖人傳心, 教天下以仁也。

25 参見：杜保瑞，2006 年 6 月, 〈朱喜經典詮釋中的工夫理論〉, 《揭諦》, 第 11 期, 頁 1-60 
胡宏此文即是將天地視為一有價值目的性的存在, 此一價值意義 當然是儒家的標的, 並言此中有道, 聖人即此有道之天地之子, 說為 之子是要說傳承上的必然性, 聖人以此道之體為性, 以此道之用為心, 性必將動, 動時即以心說, 這是本體論的存有架構, 這個架構說完了 之後, 即指出聖人之作為即是應傳此心, 傳此心即實現此道, 儒家的 天地之道本就是以仁概念為中心的價值意識, 因此聖人傳心即應教天 下以仁, 這是本體工夫論的路數。胡宏此說即是以天地之道為聖人之 本源, 聖人之實踐即是天道之落實顯現, 聖人之性以道為體, 聖人之 心以道為用。此說無甚新奇, 自周敦頣、張載以降幾乎已經都說過類 似的話了, 因此實在談不上什麼哲學創造之貢獻, 這基本上是一個由 形上學建構以說實踐的理論模式, 有存有論也有本體論, 朱子則是從 存有論進路批評胡宏：

朱子曰: 心性體用之云, 恐自上蔡謝子失之。此云「性不能不動， 動則心矣」, 語尤未安。凡此 $「$ 心」字, 皆欲作「情」字, 如何? …… 朱子日：此段誠不必存, 然「性不能不動」此語卻安, 但下句卻 有未當爾。今欲存此以下, 而頗改其語云：「性不能不動, 動則 情矣。心主性情, 故聖人教人以仁, 所以傳是心而妙性情之德。」 又案：伊川有数語, 說心字皆分明, 此一段卻難曉, 不知「有形」 二字合如何說。

朱喜這個批評的重點即在 $「$ 心性」概念的安排使用上, 朱喜以「心 統性情」架構說道德實踐主體的存有結構, 這是存有論哲學所討論的問 題。朱喜的架構是一個實踐的主體 $「$ 心, 有其應然的原理「性」, 與其 展現於實際行為時的狀態 $「$ 情」, 朱喜的架構不是用在說明實踐行動的, 而是用在說明主體結構的, 這就是存有論哲學, 牟宗三先生說這是只存 
有而不活動的存有論系統。至於說實踐行動的語句其實是「盡心」「傳 心」這樣的話語。朱喜以「心統性情」的存有論架構批評胡宏之「動則 心矣」的話，而認為應該是 $「$ 動則情矣」。胡宏之「心性」架構是以用說 心, 以體說性, 而朱喜將主體在行動的狀態說為情, 故必改心為情以言 動。其實, 存有論討論的特色就是藉由概念定義以說概念關係而建立思 考模式, 概念應該如何使用只是約定的結果, 並沒有什麼必然性, 朱喜 有新的思考模式及概念系統, 胡宏也有傳統的概念使用系統, 可以比較 差異卻母須爭論對錯。

依據胡宏之說, 聖人本天地, 聖人即道的落實, 故而道體即聖人之 性, 道用即聖人之心, 道必是要用的, 故而聖人即傳心教民以仁, 此說 有體有用有實踐, 除了概念定義的存有論討論之外, 也說到了實踐哲學 的本體工夫論, 義理上沒什麼欠缺的。朱喜必欲以情說心動之狀態, 這 卻遺漏了心動的工夫實踐義, 只注意及那行動後之狀態陳述之用詞, 卻 不重視那行動本身之心念意志之實踐之動力, 此即筆者說朱喜為存有論 地說, 而胡宏為本體工夫論地說之差別之意。

\section{五、結論}

以上對《知言疑義》進行全文疏解, 及基本哲學問題意識之整清, 重點在澄清朱喜與胡宏兩造的哲學問題意識的差異, 從而解消他們之間 的意見衝突, 顯見胡宏之學多是一恰當且一般的儒學義理, 是把本體論 與工夫論合在一起講的本體工夫論系統, 而朱喜的批評多是落語太快, 也是他對於別人的哲學命題的理解不足所致，但那也正是因為他對自己 的哲學體系十分清楚所致, 若非朱喜創造了一套義理清晰、宗旨明確的 本體論、存有論哲學及工夫次第論, 他也不致於老是以這套系統來非議 
他人, 正是他的創造力使得他誤解了他人的作品, 或者倒過來說, 正是 他的錯誤理解而創造了他自己的哲學系統。

首先, 朱喜以存有論問題意識批評胡宏, 即其以「心統性情」之人 性主體之存有論架構批評胡宏之任何涉及此些概念的命題, 如胡宏言於 $「$ 性體心用」「盡心成性」等, 其實這些命題都不是朱喜的問題意識下之 文義, 胡宏只是把本體工夫論合一地說而已。朱喜之「心統性情」說, 是對道德實踐主體進行存有架構之解析, 就實踐主體的認識架構及實踐 活動之歷程意義予以定位, 以主體的心性情架構說明去惡從善的實踐活 動意義。

其次，朱喜以「性善本體論」的思路批評胡宏若干善惡相渾的哲學 語句, 如 $\ulcorner$ 天理人欲同體異用」之說, 胡宏論述善惡問題有多層次的思 路, 而朱喜的思路明確, 只有一路, 就是儒家的形上道體是性善本體的 一路, 此義亦是儒學之必然藴含, 不能否定, 但是哲學問題層次廣泛, 現象上善惡相對的事實說明、主體為惡的可能性說明、最高境界的善惡 消泯等等, 都是胡宏可以論述的路徑, 而朱喜只管一路, 因而對胡宏之 說頗有攻擊, 這樣做固然凸顯了朱喜體系建構有成之事實, 卻也因此束 縛了儒家義理陳述的面向。

第三是朱喜以「涵養重於察識」之工夫次地論批評胡宏的本體工 夫之發言, 工夫理論亦有多重, 朱喜形成了自己的理論以後, 就不易 理解他人的討論路線, 便始終以自己的思考來理解並批評他人論工夫 之說。朱喜重視工夫次第的問題, 重視知識的學習及平日的涵養, 認 為這樣在碰到大事的時候才能做出正確的抉擇, 並能持守得住。而胡 宏關切的則是這個正確抉擇的當下行動的知識意義, 朱喜關切的是為 這個行動作事前準備的重要性, 這樣的差異卻被朱喜慎重其事地以有 衝突而展開來。 
在《知言疑義》中尚有二文是胡宏的語錄對答體的論述, 而朱喜卻 對內文所述展開義理批評, 但是這兩段文字根本就是印證境界的語錄體 文字, 並不是在作知見發言, 朱喜不解, 以為胡宏在繁有介事地進行知 識論述, 因此展開批評。這樣的批評, 就讀者而言, 當作展示朱喜的哲 學立場來認識則可, 當作胡宏的義理陳述則不可, 因為印證境界的語錄 文字, 都不是在做知識建構, 而是在討論問題的情境中做工夫操作的活 動, 因此文中的概念是在作為活動的工具被使用而不是作為知識的主題 在界定, 因此朱喜是把一套根本不是知識論述的材料當作知識論述來檢 討, 這樣的批評是文不對題的。 


\section{參考文獻}

\section{引用書目}

\section{原典}

胡宏《胡宏集》, 吳仁華點校, 中華書局 1983。

黃宗羲《宋元學案》, 全祖望補修, 陳金生、梁運華點校版, 中華書局。

\section{當代著作}

牟宗三《心體與性體》, 臺北, 正中書局 1983 。

金春峰《朱喜哲學思想》, 臺北, 東大書局 1998 。

\section{參考書目}

王立新《胡宏》, 臺北, 東大圖書公司 1996 。

朱漢民《湘學原道錄》, 中國社會科學出版社 2002。

向世陵《善惡之上・胡宏性學理學》, 中國廣播電視出版社 2000 。 杜保瑞、陳榮華《哲學概論》, 臺北, 五南出版社 2008。

陳來《宋明理學》, 遼寧教育出版社 1991 。 
《國立臺灣大學哲學論評》第三十七期 